\title{
水理模型実験による現地海岸に適用する 透水層海浜安定化工法の検討 EXPERIMENTAL INVESTIGATION ON THE APPLICATION OF GRAVITY DRAINAGE SYSTEM FOR BEACH STABILIZATION TO THE FIELD
}

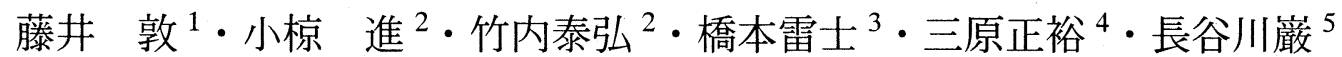

Atsushi FUJII, Susumu OGURA, Yasuhiro TAKEUCHI, Raishi HASHIMOTO, Masahiro MIHARA and Iwao HASEGAWA

\author{
${ }^{1}$ 正会員 工修 国土交通省 中部地方整備局 名古屋港湾空港技術調査事務所（同下） \\ ${ }^{2}$ 国土交通省 中部地方整備局 名古屋港湾空港技術調查事務所（T457-0833 名古屋市南区東又兵衛町 1-57-2） \\ ${ }^{3}$ 国土交通省 中部地方整備局 四日市港湾工事事務所（广510-0051 四日市市千歳町 9-1） \\ ${ }^{4}$ 株式会社エコー 沿岸デザイン本部 環境水工部（T221-0052＼cjkstart横浜市神奈川区栄町 10-35） \\ 5 正会員＼cjkstart株式会社エコー＼cjkstart沿岸デザイン本部＼cjkstart環境水工部（†221-0052＼cjkstart横浜市神奈川区栄町 10-35）
}

\begin{abstract}
The seawall has been constructed at Karasu district of Tsu-Matsusaka port on the west side of Ise bay, because of the present seawall is getting decrepit. In front of the seawall is sandy beach, however, the sand fill will be done as an Integrated Shore Protection System at the part where less beach width, and also the Gravity Drainage System for beach stabilization will be constructed to keep the fill sand. Gravity Drainage System is the beach protection technique of controlling a groundwater level by burying a permeable layer under the foreshore. The design method of Gravity Drainage System is not established because there are less construct precedents of this system at the field. Accordingly, they buried permeable layer partially at the field and carried out the field observation for designing the Gravity Drainage System. But they could not take enough data to investigate the plane arrangement because of the field observation carried out narrow area. This three dimensional hydraulic model experiment were done to investigate the necessity of beach protection works and the adequate plane arrangement.
\end{abstract}

Key Words : gravity drainage system for beach stabilization, hydraulic model experiment, integrated shore protection system, sand fill

\section{1.はじめに}

伊勢湾の西側に位置する津松阪港香良洲地区では 護岸の老朽化が進んだため，既存の護岸の海側に新 たな護岸を建設中である。護岸の前面は砂浜である が，浜幅が狭い部分には，面的防護工法として護岸 の前面に養浜を行い, 養浜砂を維持するために透水 層埋設による海浜安定化工法を適用する予定である。 透水層埋設による海浜安定化工法は現地への適用事 例が少なく，設計法が確立されていない。 そこで, 現地海岸に部分的に透水層を埋設して, 設計に用い る基礎データの収集を行った。しかし，現地試験施 工は狭い範囲でしか実施できなかつたため, 透水層 の平面的な配置を検討するのに十分なデー夕は得ら
れなかった.そこで, 三次元水理模型実験を実施し, 海浜安定化工法の必要性の検討亡, 透水層の適切な 配置に関する検討を行った。

\section{2. 現地自然条件}

香良洲地区の現況は写真-1のとおりである.海岸 延長は約 $2.8 \mathrm{~km}$ で, 河川にはさまれた河口デル夕の ような立地条件である.北側端部から海浜延長の $1 / 3$ 程度の部分は浜幅が広く, 写真-1において砂浜部が 白く見える。これに対し，南側の $2 / 3$ 程度は浜幅が 狭く, 護岸の建設と共に養浜を実施する予定である.

香良洲地区は伊勢湾の西奥にあるので，外洋の波 浪の影響はほとんど受けず，設計波が $H_{1 / 3}=3.9 \mathrm{~m}$ で 
$T_{1 / 3}=6.3 \mathrm{~s}, 5$ 年確率波が $H_{1 / 3}=2.2 \mathrm{~m}$ で $T_{1 / 3}=5.0 \mathrm{~s}$ である. H.W.L.が T.P.+0.94m で，L.W.L.は T.P.-1.02m である ので, 潮位差は約 $2 \mathrm{~m}$ である. 前浜の砂は中央粒径 $D_{50}$ が $0.4 \mathrm{~mm}$, 密度は $2.6 \mathrm{~g} / \mathrm{cm}^{3}$ である。養浜材料は 現地と同じ $D_{50}=0.4 \mathrm{~mm}$ の砂にする予定である.

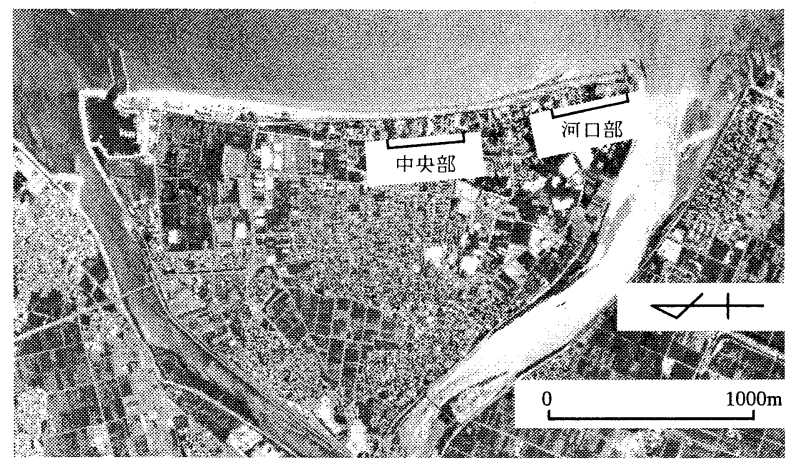

写真-1 香良洲地区海岸周辺の空中写真（1995 年）

\section{3. 実験条件と実験方法}

模型実験は, 現地の侵食事例を実験水槽に再現し 得る実験波高を決定するための再現実験と, 養浜地 形の変化を確認する養浜実験の 2 種類を実施した.

造波水槽は, 規則波と不規則波の発生が可能な造 波板長 $19 \mathrm{~m}$ のピストン型造波機を備えた, 長さ $30 \mathrm{~m}$ ×幅 $19 \mathrm{~m} \times$ 高さ $1.2 \mathrm{~m}$ を使用した. $19 \mathrm{~m}$ 幅の実験水 槽に延長が $2.8 \mathrm{~km}$ の砂浜全体を再現することはでき ないので, 実験水槽を 2 つに仕切り, 写真-1 に中央 部および河口部として示した部分を $1 / 40$ 縮尺で再 現した。現地の海底地形は汀線とほぼ同様な形状の 等深線であること, 汀線に対してほぼ直角入射とな る $\mathrm{ENE} \sim \mathrm{E} \sim \mathrm{ESE}$ の波浪発生頻度が 81.7\%であるこ と, 深浅測量結果や汀線変化計算の結果より沿岸漂 砂は極めて緩やかであること，などから，実験水槽 においては平行等深線の海底地形に対して直角方向 から波を入射させる条件とした。

\section{（1）再現実験の条件と方法}

再現実験では, 導波板を使って実験水槽内に $2.5 \mathrm{~m}$ 幅（現地換算で $100 \mathrm{~m}$ ）の水路をつくり，この中に 再現対象の初期地形を作成した. 図-1の細線が侵食 前の初期地形で，太線が侵食後の地形である．この 侵食は 2000 年 8 月 31 日の時化によるもので, 当日 の 2 時から 18 時に対象海岸前面の水深 $10 \mathrm{~m}$ 地点で 観測した有義波高 $H_{1 / 3}$ と有義波周期 $T_{1 / 3}$, および津 松阪港で観測された潮位 $\eta$ の経時変化は図-2 のと おりである. 図-1 の破線は, 対象期間中の最大潮位 と最低潮位である. 再現実験の波浪条件は，この時 化の有義波高の最大值を採用して, $H_{1 / 3}=1.32 \mathrm{~m}$ で $T_{1 / 3}=4.5 \mathrm{~s}$ （10 時）とした. 実験波浪は侵食や堆積の コントラストが明確に現れやすい規則波とした.

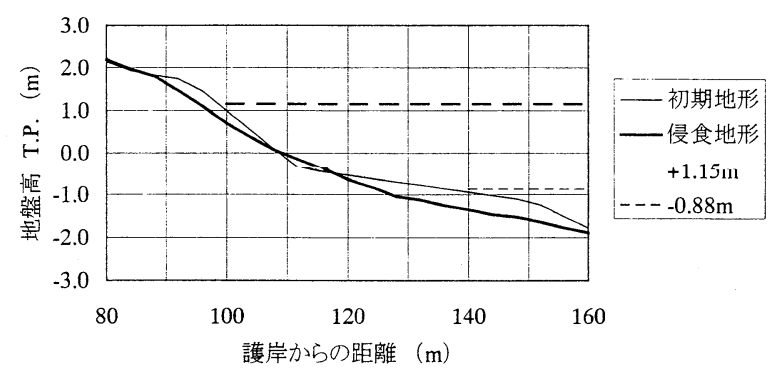

図-1＼cjkstart現地で観測された侵食事例

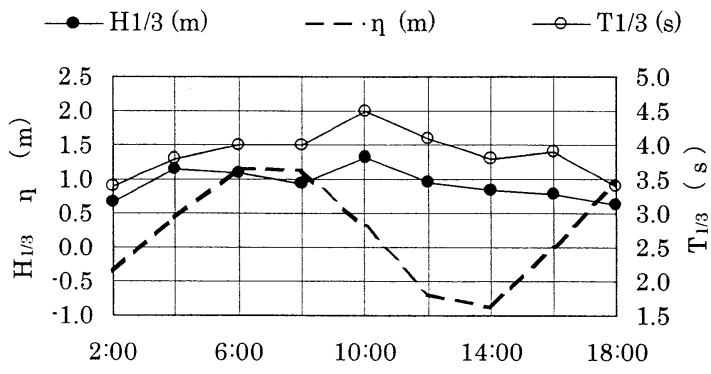

図-2 侵食事例の波高・周期・潮位の経時変化

透水層埋設による海浜安定化工法では, 砂層内の 浸透流を取り扱うため, 模型実験に適用する砂の選 定にあたっては, 地形変化の相似性の他に砂の透水 性についても現地との相似性に配慮する必要がある. 模型縮尺 $1 / 40$ の場合に, 現地の養浜に適用される $D_{50}=0.4 \mathrm{~mm}$ の砂と透水係数が相似になる実験砂の粒 径を, 山口 ${ }^{1)}$ による透水係数 $k=100 D_{10}{ }^{2}$ を適用して 検討すると $D_{50}=0.16 \mathrm{~mm}$ となる. 周期はフルードの 相似則にしたがって縮小し, Sunamura and Horikawa ${ }^{2)}$ の海浜安定化定数 $C$ を用いて $0.16 \mathrm{~mm}$ の砂の場合に 汀線変化が相似になる実験波高を検討すると, 波形 勾配が 0.12 を超える結果となり, 適用不可能と判断 した. そこで, 波高と周期をフルードの相似則で縮 小した場合に $C$ 值により汀線変化が相似になる砂の 粒径 $D_{50}=0.03 \mathrm{~mm}$ と, 砂の透水係数が相似となる $D_{50}=0.16 \mathrm{~mm}$ の平均的な粒径として, $D_{50}=0.1 \mathrm{~mm}$ の害 験砂を適用した. 実験波高は, この砂の場合に $C$ 值 による汀線変化が相似になるように算定した $6.9 \mathrm{~cm}$ を基本とした. ただし，結果的に透水係数が相似に なっておらず，また，この波高を適用しても地形変 化が相似になるかが不明である。 そこで，現地で観 測された海浜断面変化を実験水槽に再現する実験を 実施して, 養浜地形の変化予測実験に適用する実験 波高を決定することとした。

地形変化を相似にするために，実験波高はフルー ド則による波高よりも大きく設定した.したがって, 実験潮位は時化の期間中の最高潮位よりやや低い H.W.L.とした.

再現実験では, 3 測線の海浜断面, 地下水位の岸 沖方向分布，及び波高の測定を行った．海浜断面は レベルを用いて測量を行った．地下水位測定には自 作の地下水位計とマノメー夕を使用した。 波高測定 
には容量式波高計を使用した。

香良洲地区は河川に囲まれているので，砂浜の地 下水位は河川水位の影響を受けている。現地観測結 果から侵食再現対象とした時化の際の護岸周辺の地 下水位を調べると T.P. $+0.5 \mathrm{~m}$ であったので，これも 実験水槽に再現することとした，ただし，前述のと おり砂の透水性が相似になっていないので， $v=k \cdot i$ $(v$; 浸透流速, $k$; 透水係数, $i$; 動水勾配）の式で 浸透流速 $v$ が相似になるような動水勾配 $i$ を求め, これを満足するように陸側地下水位を調整した。

\section{（2）養浜実験の条件と方法}

養浜実験は, 幅 $19 \mathrm{~m}$ の実験水槽を $2 つ に$ 仕切って, 中央部と河口部の実験を同時に実施した. 実験は, 透水層なしの場合と透水層の配置を 3 種類に変更し た透水層ありについて実施し，香良洲地区に最適な 透水層配置の検討を行った，波浪条件は，侵食再現 波浪と 5 年確率波の 2 種類とし，それぞれ 5 時間ず つ作用させた．潮位が高いほうが養浜の安定に対し て厳しい条件となることから，実験潮位は H.W.L. とした.なお， 5 年確率波の場合にも遡上の高さが T.P. $+2 \mathrm{~m}$ 程度であり, 養浜の天端高 $+2.5 \mathrm{~m}$ には届かな かった. そこで，5年確率波の場合に養浜の天端ま で波が遡上するように，潮位を T.P.+1.78m まで高く したケースも実施した。ただし，このケースは波作 用時間を 1 時間とした.

佐藤ほか ${ }^{3)}$ などに示されているように，砂浜の地 下水位が潮位よりも高い状態では，水位差がない状 態よりも砂浜の侵食を受けやすいことが知られてい る. そこで, 砂浜の安定に対して厳しい条件として, 護岸背後の水位を潮位より高くすることにした．現 地における 14 ケ月間の地下水位観測によると, 護岸 より内陸側の地下水位が T.P. $+1.5 \mathrm{~m}$ を超える頻度が $3 \%$, T.P. $+1.2 \mathrm{~m}$ を超える頻度が約 $10 \%$ あったので， 護岸背後の水位を 5 年確率波では+1.5m, 侵食再現 波浪では+1.2m に設定した。なお，実験水槽におい ては，砂中浸透流速が現地と相似になるように，再 現実験と同じ方法で護岸背後の水位を調整した.

実験に適用した海浜断面は図-3 のとおりである. 養浜断面は, 計画断面どおり天端高は T.P.+2.5m で, 前浜勾配を 1:15 とした. 透水層の二次元的な配置は 図-4のとおりで, 透水層の陸側端部は護岸の根入れ 部とし，沖側端部は Kanazawa ほか49 の方法を参考 に, L.W.L.の水際線の直下に設定した. 柳嶋ほか 5)に よって示されているように，排水口は汀線付近に設 置することが可能であり，香良洲地区における試験 施工でも，この方法で透水層の効果が得られること を確認済みであるので，排水口位置は汀線のやや沖 側に設定した。

透水層の材料は Kanazawa ほかと同様にエキスパ ンドメタルを箱型に整形して，上木シートとプシン クトンネットを巻きつけた構造とした。 土木シート
とプランクトンネットは実験に適用する砂の透水係 数よりも透水性が十分に高いものを使用した．透水 層の平面的な配置は, 透水層の埋設密度が $50 \%$ で透 水層幅が $6 \mathrm{~m}$ と $24 \mathrm{~m}$ (いずれも現地換算) の場合と, 透水層の埋設密度が $30 \%$ (透水層幅が $10 \mathrm{~m}$ で透水層 隙間部の間隔が $24 \mathrm{~m}$ ）の場合の 3 種類とした.

養浜実験では, 地形, 地下水位, 波高分布, 流況 分布の測定を行った. 地形はレベルを使用して岸沖 方向に $10 \mathrm{~cm}$ （現地で $4 \mathrm{~m}$ ）間隔, 沿岸方向に $50 \mathrm{~cm}$ （現地で $20 \mathrm{~m}$ ）間隔で測定した.ただし，50\%，24m のケースと $30 \%$ ケースでは, 沿岸方向の測線を透 水層の中心と隙間部の中心に変更した.
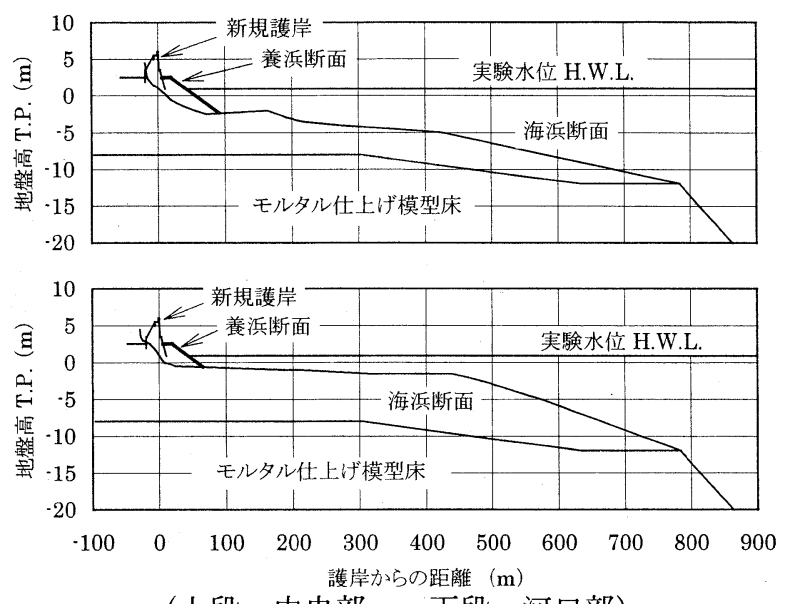

（上段 ; 中央部，下段 ; 河口部）

図-3 実験に適用した海浜断面形状

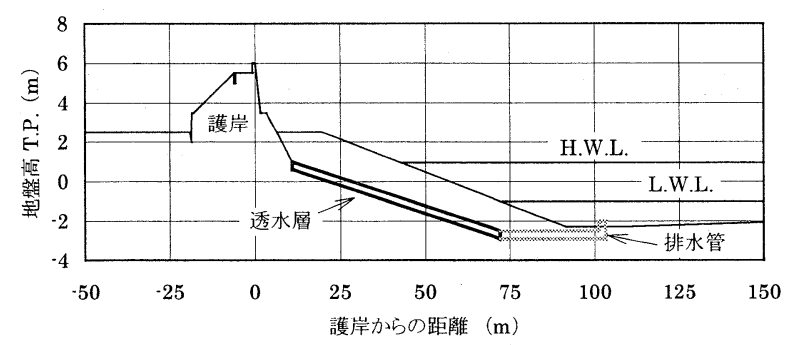

図-4 透水層と排水管の二次元的配置

\section{4. 実験結果}

\section{（1）地形変化の再現性}

地形変化量を波作用時間で割って単位時間あたり の地形変化量としたものを地形変化速度と定義し, 模型時間で 5 時間の波作用の経時変化を見ると図 -5 のとおりである.地形変化量は堆積を正の值とした。 地形変化量と護岸からの距離はフルード則で現地換 算してあるが, 波作用時間は模型時間のままである.

図-5 を見ると, 波作用の初期段階では地形変化速 度が大きいが，波作用時間の経過と共に徐々に小さ くなっている. 5 時間後にはかなり小さな值となっ ているこしから，模型実験においては波作用を5洔 間で終えることにした。 


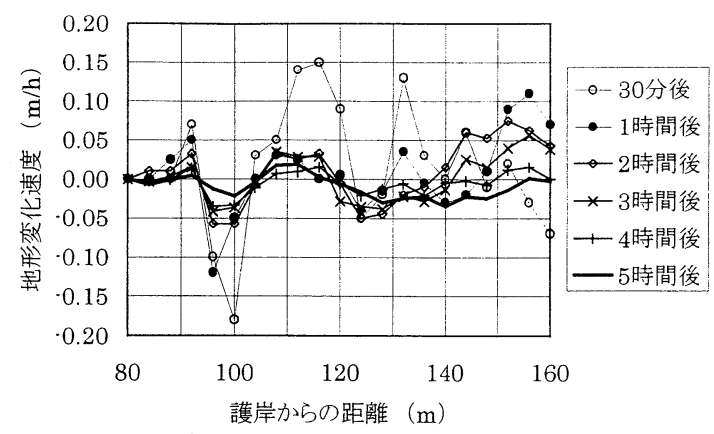

図-5 地形変化速度の経時変化

波高 $6.9 \mathrm{~cm}$ の波浪を模型時間で 5 時間作用させた 場合の地形変化速度を, 現地の地形変化速度と比較 すると図-6 のとおりである. 現地侵食事例の波浪の 経時変化は前掲図-3に示したとおりで, 波高が $0.8 \mathrm{~m}$ を超えている期間が 10 時間であることから, 現地侵 食事例の地形変化速度は, 時化の継続時間を 10 時間 として求めた。実験結果は現地侵食事例と比べて地 形変化速度の絶対值が小さいが，堆積や侵食を生じ る位置は非常に良く一致している.

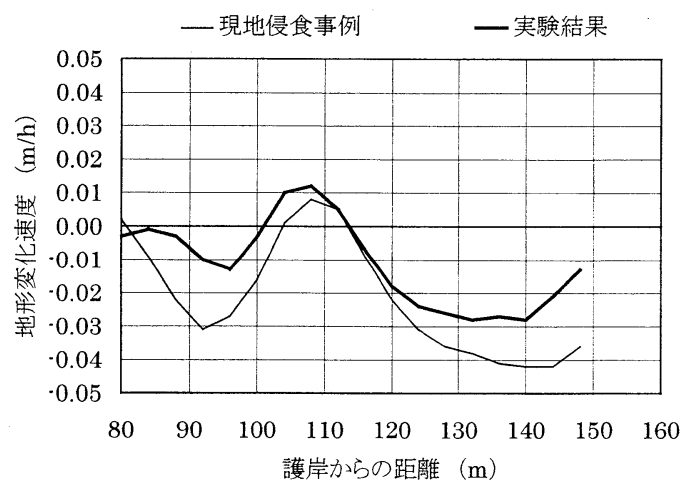

図-6＼cjkstart現地侵食事例と実験結果の地形変化速度の比較

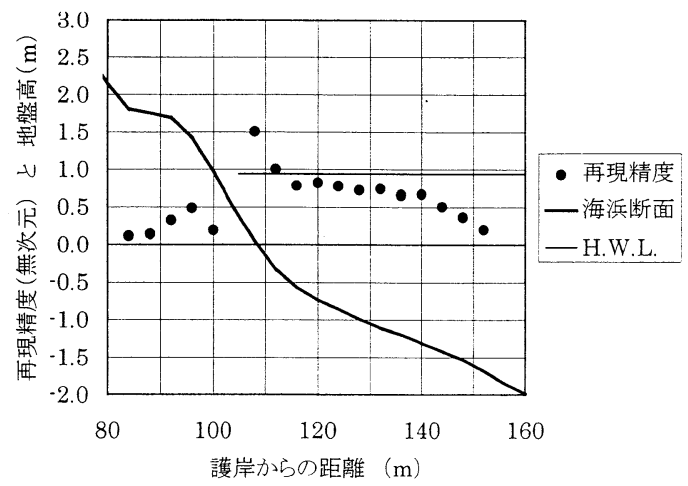

図-7 地形変化の再現精度

実験結果の地形変化速度を現地侵食事例の地形変 化速度で割ることによって地形変化の再現精度を求 めると，図-7 のとおりである，位置関係を把握でき るように，図中には海浜断面も示した。遡上の先端 付近で再現精度がやや落ちるが，その他の部分では 再現精度が比較的高く, 遡上域も含めた全体の平均
値は 0.59 である. 全体に地形変化量が不足している ので実験波高を大きくする実験も実施したが，砕波 を生じるために養浜部に到達する波高に差が現れず, 地形変化量が大きくなることはなかった. したがっ て, 養浜地形の変化を予測する養浜実験には, 侵食 再現波浪として $6.9 \mathrm{~cm}$ の波高を作用させるものとし， 再現精度を考慮して, 現地においては模型実験の 2 倍程度の地形変化を生じる可能性があるものとして 実験結果を評価することにした。

\section{（2）波高・流速分布と地形変化}

養浜実験において, 中央部に侵食再現波浪を 5 時 間作用させたケースで地形と波高を測定した結果を， 透水層なしと埋設密度 $50 \%$ で埋設間隔が $24 \mathrm{~m}$ の透水 層ありの場合とで比較すると，図-8 のとおりである. 右図の下のほうに書いた 7 個の四角い箱が透水層設 置位置である，透水層工法は構造物を砂浜に埋設す るので，波浪を制御する効果はない。したがって, 透水層なしとありで波高分布に違いは見られない。

平行等深線の海底地形に対して直角方向から波を 入射させているので, 沿岸方向に波高分布の大きな 差はなく, 沖側から岸に向かって波高が徐々に小さ くなっている. したがって, 地形変化量分布を調べ ても, 沿岸方向の漂砂は少なく, 地形変化は二次元 的であった.

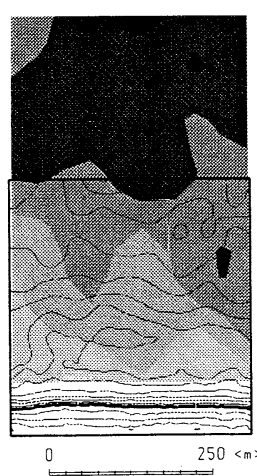

a）透水層なし

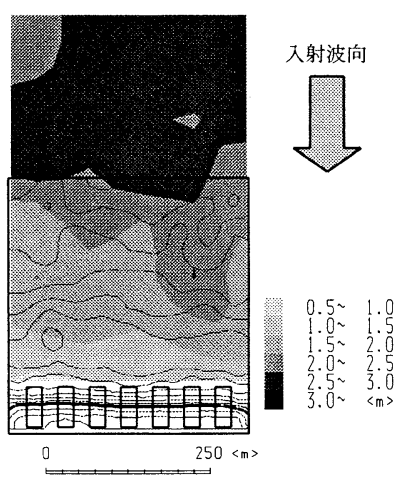

b）透水層あり $50 \%, 24 \mathrm{~m}$
図-8 波高分布と海浜地形の比較

同じケースにおいて, 電磁流速計で測定した底層 流速の分布を見ると図-9のとおりで, 透水層なしと ありの間に有意な差が認められない。この他にも, フロートの観察による表層の流況と, 染料の観察に よる中層の流況を比較したが，いずれも透水層なし とありの差は認められなかった．佐藤ほか ${ }^{6}$ には突 堤で囲った人上海浜においては，透水層の設置によ って wave set-up を生じさせないことにより沿岸流 の発生を抑制し，その結果として沿岸漂砂を軽減で きることが報告されている。これに対し，今回の実 験結果は, 仮に斜め入射で実験を実施したとしても, 構造物のない開かれた海浜に透水層を埋設する場合 
には，沿岸漂砂を抑制する効果は得られない可能性 が高いことを示唆しているものと考えられる.

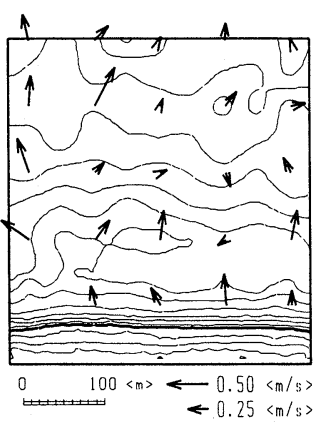

a）透水層なし

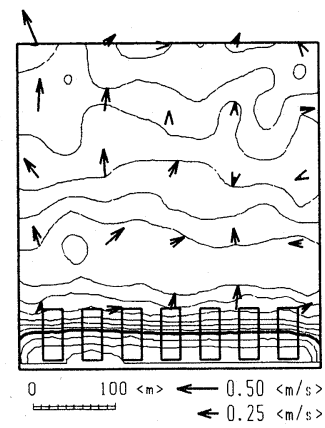

b）透水層あり $50 \% ， 24 \mathrm{~m}$

\section{（3）地下水位上昇の抑制}

中央部に侵食再現波浪を作用させた場合の透水層 なしの地下水位上昇量は, 図-10の×印のとおりで, 透水層を $50 \%$ の密度で $6 \mathrm{~m}$ 間隔で埋設した場合は 印である. ○印は地下水位上昇量が小さく, 細かい 間隔で透水層を設置しているために沿岸方向にほぼ 均一に地下水位上昇が抑制されている.これに対し， 透水層の埋設密度が $50 \%$ で間隔を $24 \mathrm{~m}$ とした場合と， 埋設密度 30\%で隙間部の幅を $24 \mathrm{~m}$ とした場合には, ○印と $\triangle$ 印の透水層上では地下水位上昇が抑制され ているものの, ○印と $\Delta$ 印の隙間部では地下水位の 上昇を生じている．ただし，隙間部の地下水位上昇 量は透水層なしの場合よりは小さく，十分ではない ながらも透水層による地下水位上昇抑制効果が及ん でいることがわかる.

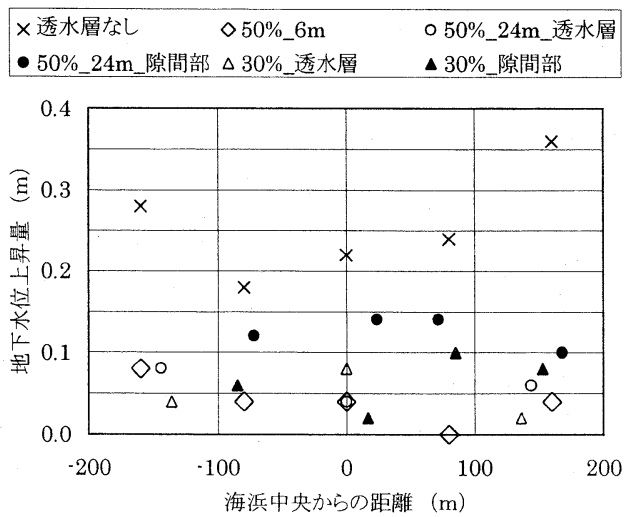

図-10 養浜法肩位置における地下水位上昇量の比較

\section{（4）香良洲地区に適した透水層条件の検討}

\section{a）中央部の検討}

中央部において透水層なしと 3 種類の透水層を埋 設した場合の，侵食再現波浪 5 時間の波作用後の海 浜断面を比較すると，図-11 のとおりである，透水 層なしでも初期汀線位置には砂が堆積しているが, 透水層ありでは透水層なしよりやや高い位置に堆積
している. そのため，図-12 に示した初期汀線位置 の岸沖漂砂量を見ると, 透水層なし（埋設密度 $0 \%$ ) と比べて透水層ありのほうが大きな值を示している. 岸沖漂砂量が正の值であるので, 汀線よりも沖側か ら砂が流入していることになり，その流入量は透水 層の密度の濃いほうが多い。つまり透水層埋設によ る堆積促進効果が現れている.

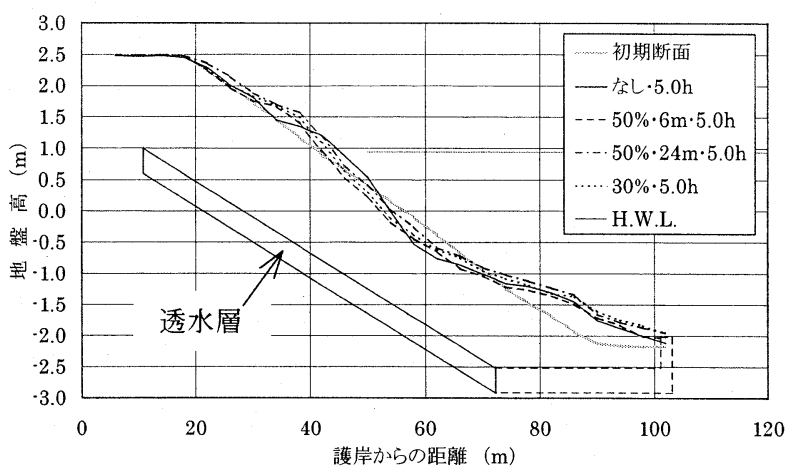

図-11 5 時間後の海浜断面の比較（中央部）

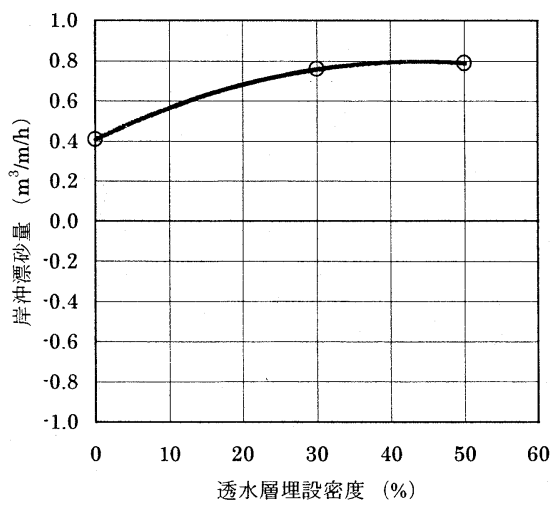

図-12 侵食再現波浪 5 時間の作用による初期汀線位置の 岸沖漂砂量 (中央部)

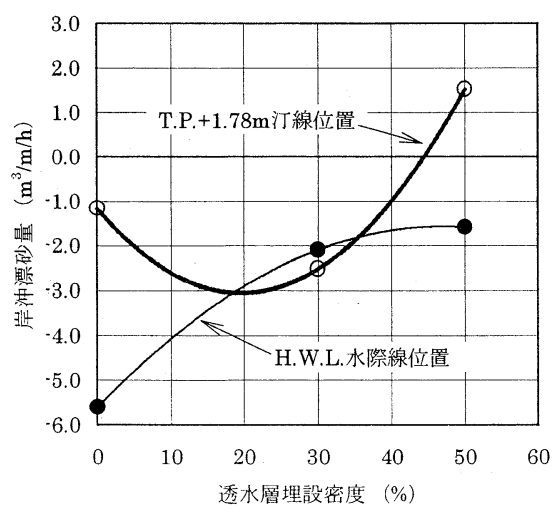

図-13 5 年確率波・天端遡上潮位 1 時間の波作用による 岸沖漂砂量（中央部）

侵食再現波浪では汀線位置で侵食を生じなかった が，5 年確率波の場合には侵食を生じた。養浜の天 端まで波が遡上する潮位 T.P.+1.78m の汀線位置と H.W.L.水際線位置での岸沖漂砂量は図-13 のとおり 
で，透水層なしでは侵食しているのに対し，透水層 ありでは侵食を堆積に転じさせる，あるいは侵食を 軽減する効果が得られている. グラフの分布は基本 的には右上がりの傾向を示しており, 透水層の密度 が濃いほど海浜安定化効果が高い結果である。この 他にも, 汀線変化や地下水位上昇抑制効果について も検討を行い，中央部における透水層の埋設密度は $50 \%$ 適切であると判断した.

透水層の埋設間隔に関しても同様な検討を行った。 一例として,地下水位上昇量による検討結果を図-14 に示す。透水層なしを埋設間隔が無限大として取り 扱い, 図の横軸を埋設間隔の逆数としてゼロの位置 にプロットした. $24 \mathrm{~m}$ 間隔と $6 \mathrm{~m}$ 間隔のデータは埋 設密度 $50 \%$ ののである. $24 \mathrm{~m}$ 間隔のデー夕は, 透 水層上と隙間部の上昇量の平均値を採用した.

$24 \mathrm{~m}$ 間隔には隙間部分の上昇量がやや大きいデー 夕を含んでいるので，地下水位上昇が均一に抑制さ れている $6 \mathrm{~m}$ と比べると，やや大きな值となってい る.しかし, 別途測定した排水口位置における $0.05 \mathrm{~m}$ の wave set-up を基準に考えれば, 上昇量は $0.05 \mathrm{~m}$ だ けと見ることができる．したがって，透水層の埋設 間隔は $24 \mathrm{~m}$ 程度まで広げることが可能と判断した.

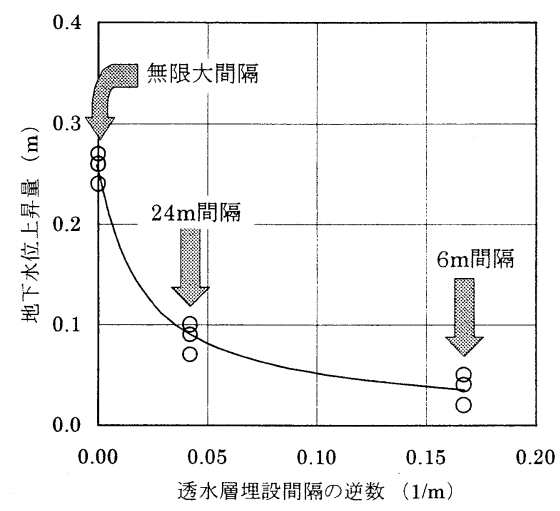

図-14 透水層埋設間隔の検討（中央部）

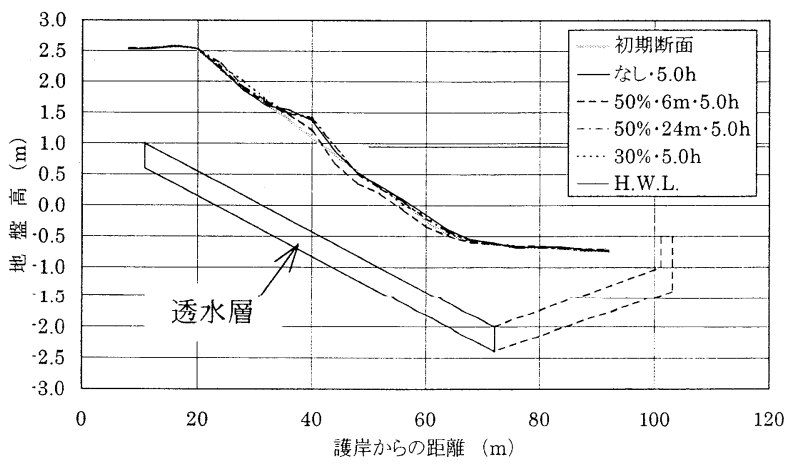

図-15 5 時間後の海浜断面の比較（河口部）

\section{b）河口部の検討}

河口部において透水層なしと 3 種類の透水層を埋 設した場合の，侵食再現波浪 5 時間の波作用後の海 浜断面を比較すると，図-15 のとおりである．同時
に実験を実施しているので波浪条件は中央部と同じ であるが，河口部の地形変化は図-11 の中央部より 明らかに小さい。これは，河川からの流下土砂が遠 浅の河口砂州を形成しているために, かなり沖合い で砕波することによって，養浜部に到達する波高が 小さくなるためである. 5 年確率波のケースでも同 様な結果であったので, 河口部においては海浜安定 化工法を適用する必要性が低いと判断した。

\section{5. まとめ}

この検討によって得られた成果をまとめると，以 下のとおりである.

(1)定量的には $1 / 2$ 程度の精度であるが，定性的には 非常によい精度で害験水槽の地形変化を現地と相 似にすることができた。

(2)透水層埋設は岸沖方向の漂砂に対して有効であり, 透水層を密に埋設するほど海浜安定化効果が高い. ただし，構造物のない開かれた海浜において沿岸 漂砂を抑制することは難しいと考えられる.

(3)透水層はストライプ状に埋設することが可能で, 香良洲地区の中央部の場合には, 最適な埋設密度 が $50 \%$, ストライプの間隔は $24 \mathrm{~m}$ 程度まで広げ ることができる.

今回の模型実験によって津松阪港香良洲地区の養 浜に適用する透水層工法の配置を検討した．今後は 模型実験の成果を生かして現地試験施工と現地調査 を実施し，最適な透水層条件の検討を続ける予定で ある。

\section{参考文献}

1)山口柏樹 : 土質力学, 技報堂出版, 389p.

2)Sunamura, T. and Horikawa, K. : Two-dimensional beach transformation due to waves, Proc. 14th Coastal Eng. Conf., ASCE, pp.920-937, 1974.

3)佐藤道朗, 鋲賀一博, 口八町誠, 福島博文, 森 芸: 摺 ケ浜の砂流失に関する現地観測, 第 29 回海岸工学講演 会論文集, pp.314-318, 1982.

4)Kanazawa, H, Matsukawa, F, Katoh, K, and Hasegawa, I.: Experimental study on the effect of gravity drainage system on beach stabilization, Proc. 25th ICCE, pp.2640-2653, 1996.

5)柳嶋慎一, 加藤一正, 荒田昌潔, 松本 茂, 平戸誠一郎, 堀 謙吾: 透水層工法における排水口土被りと排水流量 の関係，海岸工学論文集，第 46 巻，pp.721-725，1999. 6)佐藤恒夫, 榊 俊博, 柴田 悟, 込山 清, 平松和也, 長谷川篇: 海浜安定化に関する透水層埋設の三次元的効 果, 海岸工学論文集, 第 46 巻, pp.711-715, 1999. 